\title{
CONSTITUENTS OF ESSENTIAL OILS FROM LEAVES AND SEEDS OF FOENICULUM VULGARE MILL. CULTIVATED IN BANGLADESH
}

\author{
Jasim Uddin Chowdhury, Md. Hosnay Mobarok, Md. Nazrul Islam Bhuiyan* \\ AND NeMAi ChandRa NANDi
}

BCSIR Laboratories, Chittagong, P.O. Chittagong Cantonment, Chittagong-4220, Bangladesh

Key words: Foeniculum vulgare Mill, Essential oil, Anethole, Limonene, Bangladesh

\begin{abstract}
Analysis of essential oils obtained from the seeds and leaves of Foeniculum vulgare Mill. cultivated in Bangladesh revealed that anethole was the major constituent $(58.5 \%$ in seed oil and $51.1 \%$ in leaf oil), followed by limonene ( $19.6 \%$ in seed oil and $22.9 \%$ in leaf oil). Other components present in leaf oil included anisaldehyde, fenchyl acetate and fenchone, while seed oil contained fenchone, $\alpha$-pinene, fenchyl acetate, $\gamma$-terpinene and anisaldehyde. Besides, minor constituents like camphene, camphor, myrcene, pahllandrene, ocimene, $\beta$-bisabolene and apiol were obtained from seeds and leaves.
\end{abstract}

The plant was identified by matching with voucher specimen (J-1695) preserved in the herbarium of BCSIR Laboratories, Chittagong. The essential oils were obtained by hydrodistillation method from leaves and seeds collected from the plants grown in BCSIR campus, Chittagong, during July 2006. The isolated oils were dried over anhydrous sodium sulphate.

Fennel (Foeniculum vulgare Mill., Family Umbelliferae), is a perennial or annual herb and a typical aromatic plant that grows and grown all over the world for its fruits used as culinary spice. The oils from leaves and seeds of $F$. vulgare were analyzed by electron impact ionization method on GC-17A Gas Chromatograph (Shimadzu) coupled to a QP 5050A Mass Spectrophotometer (Shimadzu). A fused capillary column (column $30 \mathrm{~m}$ x $0.25 \mathrm{~mm}, 1 \mu \mathrm{m}$ film thickness) coated with DB-5 ms (J\&W) was used. Direct injection of $1 \mu \mathrm{l}$ sample with He as a carrier gas (at a pressure of $100 \mathrm{Kpa}$ ) and oven temperature held isothermal at $50^{\circ} \mathrm{C}$ for $4 \mathrm{~min}$ and then programmed to increase at $10^{\circ} \mathrm{C} / \mathrm{min}$ to $150^{\circ} \mathrm{C}$ with keep time of $5 \mathrm{~min}$ which was further programmed to increase at $10^{\circ} \mathrm{C} / \mathrm{min}$ to $250^{\circ} \mathrm{C}$ with a keep time of $5 \mathrm{~min}$. Acquisition parameters: full scan; scan range $40-300^{\circ} \mathrm{C}$, ionization voltage $70 \mathrm{ev}$. The essential oil composition was identified by comparing the mass spectra from NIST Library (NIST 147 \& NIST 27).

In oils, anethole (51.08\% and $58.54 \%$ in leaves and seeds, respectively) and limonene ( $22.9 \%$ and $19.6 \%$, in leaves and seeds, respectively) were found to be the major constituents. $\beta$ thujaplicin, which has recently been reported to have antifungal (Morita et al. 2004) and antibacterial (Arima et al. 2003) activity, was found in leaf oil at about $4.8 \%$. In all 30 components were identified in the seed oil and 31 in leaf oil (Table 1). The components present in the essential oil obtained from seeds and leaves of fennel cultivated in Bangladesh are similar to those reported for sweet and bitter fennel but the relative percentage of compounds such as anethole and limonene differed (Arslan et al. 1989, Embong et al. 1977). Limonene, was found in higher concentration (23\% in leaf oil and $20 \%$ in seed oil) than the previously reported essential oils of Fennel. The percentage variation of chemical composition of $F$. vulgare especially on anethole and limonene seems to be due to the different geographical location and climate of Bangladesh.

*Corresponding author: nazrul119@yahoo.com 
The oil obtained from air-dried fruits of $F$. vulgare of Turkish origin contained methyl chavicol $(47.09 \%)$, limonene $(29.07 \%)$, fenchone $(13.43 \%)$, fenchyl acetate $(1.95 \%)$, cis- $\beta$ ocimene $(1.41 \%), \alpha$-pinene $(1.22 \%)$, and myrcene $(1.08 \%)$ as the main constituents (Özcan and Akgül 2001). The major components from these were found to be methyl chavicol, trans-anethole, limonene, fenchone, $\beta$-terpinene and piperitonene oxide (Marotti 1994). Özcan et al. (2006) found estragole $(61.08 \%)$, fenchone $(23.46 \%)$, limonene $+\beta$-phellandrene +1 , 8 -cineole $(8.68 \%)$ and $\alpha$-pinene $(1.15 \%)$ as the important components of ripe fruit oil.

Table 1. Essential oil Composition of Foeniculum vulgare Mill. cultivated in Bangladesh.

\begin{tabular}{|c|c|c|c|}
\hline \multicolumn{2}{|l|}{ Seed oil } & \multicolumn{2}{|l|}{ Leaf oil } \\
\hline Compounds & Percent & Compounds & Percent \\
\hline$\gamma$-terpinene & 1.10 & $\gamma$-terpinene & 0.06 \\
\hline 3-methoxycinamaldehyde & 0.27 & 2-methoxybenzeneethanol & 0.10 \\
\hline 4-terpinolene & 0.28 & 3-methoxycinamaldehyde & 0.14 \\
\hline Anethole & 58.54 & 4-hexen-1-ol,acetate & 0.22 \\
\hline Anisaldehyde & 0.72 & Allyl-3-methoxybenzoate & 0.06 \\
\hline Apiol & 0.27 & Anethole & 51.08 \\
\hline Camphene & 0.08 & Anisaldehyde & 7.55 \\
\hline Camphor & 0.63 & Apiol & 0.63 \\
\hline Caryophyllene & 0.10 & Camphene & 0.07 \\
\hline cis-sabinenehydrate & 0.09 & Camphor & 0.04 \\
\hline Ethenyl)-2-cyclohexeneone & 1.19 & cis-verbenol & 0.18 \\
\hline Eugenol & 0.08 & Fenchone & 1.65 \\
\hline Fenchyl acetate & 1.20 & Fenchyl Acetate & 5.34 \\
\hline Germacrene & 0.47 & Limonene & 22.90 \\
\hline Isopinocampheol & 0.11 & Limonene-1,2-epoxide & 0.11 \\
\hline 1-fenchone & 7.72 & Methyleugenol & 0.07 \\
\hline Limonene & 19.63 & Methylisoeugenol & 0.12 \\
\hline Ocimene & 0.09 & Myristicin & 0.08 \\
\hline Sabinene & 0.69 & n-amyl isovalerate & 0.01 \\
\hline Terpinolene & 0.12 & Octahydro-1-benzothipene & 0.07 \\
\hline trans-limonene oxide & 0.83 & p-anisic anhydride & 0.20 \\
\hline Trans-p-mentha-2,8-dienol & 0.29 & Plinol D & 0.11 \\
\hline (S)-2-methyl-5-(1-methyl & & trans-carvyl acetate & 0.25 \\
\hline trans-verbenol & 0.15 & trans-carvyl propionate & 0.41 \\
\hline$\alpha$-phallandrene & 0.30 & trans-p-2,8-menthadien-1-ol & 0.15 \\
\hline$\alpha$-pinene oxide & 0.18 & $\alpha$-curcumene & 0.05 \\
\hline$\beta$-bisabolene & 0.08 & $\beta$-bisabolene & 0.03 \\
\hline$\beta$-camphor & 0.16 & $\beta$-myrcene & 0.63 \\
\hline$\beta$-pinene & 1.80 & $\beta$-ocemene & 0.27 \\
\hline$\beta$-pinene & 0.22 & $\beta$-phallandrene & 0.04 \\
\hline$\beta$-thujaplicine & 0.04 & $\beta$-pinene & 0.14 \\
\hline & & $\beta$-thuzaplicin & 4.82 \\
\hline
\end{tabular}

\section{References}

Arima Y., Y. Nakai, R. Hayakawa and T. Nishino. 2003. Antibacterial effect of beta-thujaplicin on staphylococci isolated from atopic dermatitis: relationship between changes in the number of viable bacterial cells and clinical improvement in an eczematous lesion of atopic dermatitis. J Antimicro. Chemotherapy 51(1): 113-122. 
Arslan N., A. Bayrak and A. Akgul. 1989. The yield and components of essential oil in fennels of different origin (Foeniculum vulgare Mill.) grown in Ankara conditions. Herba Hungarica 28(3): 27-31.

Embong M.B., D. Hadziyer and S. Molnar. 1977. Essential oils from species grown in Alberta. Fennel oil (Foeniculum vulgare var. dulce). Can. J. Plant Med. 17: 281-293.

Marotti M., R. Piccaglia, E. Giovanelli, S.G. Deans and E. Eaglesham. 1994. Effects of variety and ontogenic stages on the essential oil composition and biological activity of fennel (Foeniculum vulgare Mill.). J Essent. Oil Res. 6: 57-62.

Morita Y., E. Matsumura, T. Okabe, T. Fukui, T. Ohe, N. Ishida and Y. Inamori. 2004. Biological activity of beta-dolbrin, gamma-thujaplicin, and 4-acetyltropolone, hinokitiol-related compounds. Biol. Pharm Bull. 27(10): 1666-1669.

Özcan M. and A. Akgül. 2001. Chemical composition of the essential oil of bitter fennel (Foeniculum vulgare subsp. piperitum). J. Spices Arom. Crops 10: 49-50.

Özcan M.M, J.C. Chalchat, D. Arslan, A. Ates and A. Ünver. 2006. Comparative essential oil composition and antifungal effect of bitter fennel (Foeniculum vulgare subsp. piperitum) fruit oils obtained during different vegetation. J. Med. Food 9(4): 552-561.

(Manuscript received on 15 September, 2007; revised on 25 September, 2009) 